\title{
A VEDAÇÃO DA CRUELDADE PARA COM OS ANIMAIS NÃO-HUMANOS À LUZ DA INTERPRETAÇÃO CONSTITUCIONAL ${ }^{1}$
}

\author{
THE PROHIBITION OF CRUELTY TO NON-HUMAN ANIMALS BY THE \\ CONSTITUTIONAL INTERPRETATION
}

\begin{abstract}
Juliana Vargas Palar
Graduanda no Curso de Direito na Universidade Federal de Santa Maria (UFSM); integrante do Grupo de Pesquisa em Direitos dos Animais (GPDA) dessa instituição. Email: julianapalar@gmail.com
\end{abstract}

Nina Trícia Disconzi Rodrigues

Doutora em Direito pela Universidade de São Paulo (USP). Professora do Curso de Direito e do Programa de Pós-Graduação strictu sensu (Mestrado em Direito) na Universidade Federal de Santa Maria (UFSM). Líder do Grupo de Pesquisa em Direitos dos animais (GPDA) dessa instituição. E-mail: ninadisconzi@uol.com.br

Waleksa Mendes Cardoso

Mestra em Filosofia pela Universidade Federal de Santa Maria (UFSM). Professora da Faculdade de Direito de Santa Maria (FADISMA). Líder do Grupo de Pesquisa em Direitos dos Animais (GPDA) nessa instituição. E-mail: waleska.cardoso@gmail.com

Recebido em: 22/11/2016

Aprovado em: 10/01/2017

Doi: $10.5585 / \mathrm{rdb} . \mathrm{v} 16 \mathrm{i} 7.544$

RESUMO: A Constituição da República Federativa do Brasil de 1988 em seu art. 225, §1º, inciso VII desvinculou o tratamento dos animais não-humanos de um valor econômico e reconheceu um valor próprio a esses seres, ao vedar as práticas que coloquem os animais em extinção e os submetam à crueldade. Dessa forma, possibilitou-se uma nova perspectiva para a compreensão jurídica dos animais não-humanos, em que eles não são dispostos como "coisas" a serviço da humanidade. Todavia, a indefinição do conceito de crueldade pelo constituinte viabiliza a utilização dos animais não-humanos pelos animais humanos em situações que impliquem crueldade, sob a justificativa de que o sofrimento imposto é necessário. Contudo, a necessidade aferida é medida de acordo com os interesses humanos e os benefícios provocados à humanidade. Dessa forma, nota-se um critério antropocêntrico e especista para a aplicação dessa norma constitucional. Nessa perspectiva, questiona-se se é possível, por uma interpretação fundada em uma ética animalista, reconhecer os direitos animais através do art. 225 , $\S 1^{\circ}$, inciso VII da Constituição Federal. Com o objetivo de responder essa pergunta, o presente trabalho emprega o método de abordagem dedutivo, pois visa identificar como os magistrados conceituam a crueldade com os animais, partindo da análise da jurisprudência do Supremo Tribunal Federal.

\footnotetext{
${ }^{1}$ Artigo resultante de pesquisa realizada no Projeto "Interpretações constitucionais para a definição de crueldade com os animais não-humanos", desenvolvido no Grupo de Pesquisa em Direito dos Animais (GPDA), certificado pelo CNPq, da Universidade Federal de Santa Maria.
}

Revista de Direito Brasileira | São Paulo, SP | v. 16 | n. 7 | p. 304 - 323 | Jan./Abr. 2017 
O método de procedimento consiste no método comparativo a fim de verificar como aplicação da norma constitucional pode variar de acordo com o modo em que é interpretada, e como técnica de pesquisa, utiliza-se a pesquisa bibliográfica.

Palavras-chaves: Crueldade. Animais. Interpretação constitucional.

ABSTRACT: The Constitution of the Federative Republic of Brazil from 1988 in its article 225, $\S 1^{\circ}$, clause VII disengaged the non-human animal treatment from an economic value and it recognized an own value to these beings, when it forbids the practices which put animals in extinction and the ones which cause cruelty. In this manner, it enabled a new perspective to a juridical comprehension of non-human animals, for which they aren't seen like things to serve the humanity. However, the imprecision of the concept of cruelty by the constituting makes possible the utilization of non-human animals in situations that apply cruelty, under the excuse that the suffering caused is necessary. Nevertheless, the alleged necessity is measured according to the human interests and the benefits proportioned to the humanity. Therefore, it is noticeable an anthropocentric and specist criterion to the application of this constitutional norm. Thus, the question is if it is possible an interpretation found in an animal ethic recognizes the animal rights through the article $225, \S 1^{\circ}$, clause VII of Brazilian Constitution. With the goal of answering this question, the present work uses the deductive approach method, because it intends to identify how the judges are defining cruelty to animals, analyzing the Supreme Courte jurisprudence. The procedure method is the comparative one with the aim of checking how the constitutional norm application can vary according to the way it is interpreted, and the research technique is the bibliographical one.

Keywords: Cruelty. Animals. Constitutional interpretation.

SUMÁRIO: Introdução; 1. Artigo 225, $\S 1^{\circ}$, inciso VII da Constituição Federal de 1988: uma nova compreensão jurídica acerca dos animais não-humanos; 2. A (in)definição do conceito de crueldade para com os animais não-humanos; 2.1 A crueldade para com os animais não-humanos pela jurisprudência do Supremo Tribunal Federal; 3. Consequências de uma releitura do artigo 225, §1º, inciso VII da Constituição Federal de 1988 sob uma ética animalista; Conclusão; Referências.

\section{INTRODUÇÃO}

As Constituições brasileiras, historicamente, trataram os animais não-humanos através de um viés econômico. A ruptura com essa perspectiva somente foi proporcionada pela Constituição da República Federativa do Brasil de 1988, em vigência, que estabeleceu em seu artigo $225, \S 1^{\circ}$, inciso VII, a proteção da flora e da fauna através da vedação, na forma de lei, das práticas que colocam em risco a sua função ecológica, que causam a extinção das espécies ou submetam os animais à crueldade.

Embora a norma constitucional que dispôs sobre a situação dos animais não-humanos represente um avanço em face das demais constituições, a indefinição do conceito de crueldade pelo constituinte possibilita que a sua aplicação ocorra conforme a vontade do intérprete. Todavia, esse fundamenta suas decisões em critérios antropocêntricos e especistas. Dessa forma, insta o questionamento se é possível uma interpretação constitucional que reconheça os direitos animais através do artigo $225, \S 1^{\circ}$, inciso VII do Texto Fundamental.

Para responder essa pergunta, será necessário descobrir como os magistrados interpretam essa norma constitucional. Por isso, utiliza-se o método de abordagem dedutivo, uma vez que serão analisadas apenas as decisões proferidas pelo Supremo Tribunal Federal em sede 
de controle de constitucionalidade. Já para averiguar a possibilidade de uma interpretação constitucional reconhecedora dos direitos animais, emprega-se o método de procedimento comparativo. E, para fundamentar o exposto, a técnica de pesquisa consiste na pesquisa bibliográfica.

O trabalho se estruturará em três partes: na primeira, ocorrerá uma análise da evolução de normas que tratam dos animais não-humanos e que culminaram na proteção constitucional disposta na Constituição Federal de 1988. Na segunda parte, serão observados os fundamentos para a aplicação da vedação constitucional de submissão dos animais à crueldade pelo Supremo Tribunal Federal em controle de constitucionalidade. E, por fim, a última parte tratará de uma interpretação constitucional através de uma ética animalista defendida por Tom Regan.

\section{ARTIGO 225, §1 ${ }^{\circ}$, INCISO VII DA CONSTITUIÇÃO FEDERAL DE 1988: UMA NOVA COMPREENSÃO JURÍDICA ACERCA DOS ANIMAIS NÃO-HUMANOS}

Os primeiros indícios de uma preocupação acerca dos animais não-humanos apareceram no século XVIII através da publicação da obra "A dissertation on the duty of the mercy and the sin of cruelty against brute animals" de Humphry Primatt. Para o autor, os animais humanos devem tratar com amor e compaixão não somente seus amigos, conhecidos e vizinhos, mas também os animais não-humanos, pois esses são objetos de estima por Deus (PRIMATT, 1776).

Desde o século XVIII até os dias atuais, o debate acerca dos animais não-humanos se intensificou, sendo que a defesa pela proteção desses seres ganhou outro fundamento, que não a compaixão entre espécies como compreendia Primatt, mas pela inclusão dos animais nãohumanos no campo de consideração das teorias éticas.

Essa possibilidade foi proporcionada pelos avanços científicos que apontaram que os animais não-humanos são dotados de senciência ${ }^{2}$, racionalidade $^{3}$, autoconsciência ${ }^{4}$, percepção de que estão no mundo e daquilo que acontece com seu corpo $^{5}$, interesses ${ }^{6}$ e capacidade para aprender e utilizar a linguagem ${ }^{7}$.

\footnotetext{
2 "Ser senciente significa ser o tipo de ser que tem experiências subjetivas de dor (e prazer) e interesse em não experenciar essa dor (ou experenciar prazer) (FRANCIONE, 2013, p. 42, grifos do autor). René Descates, filósofo do século XVIII, acreditava que os animais não-humanos eram incapazes de pensar ou de sentir, uma vez que seriam desprovidos de uma linguagem dos sinais ou verbal, assim como de uma alma, que seriam atributos necessários para a existência de consciência (FRANCIONE, 2013).

3 De acordo com Carlos Naconecy (2006, p. 139): "quando um animal lida com um problema difícil, articula uma estratégia engenhosa, e constrói uma ferramenta para pô-la em prática, ele está demonstrando capacidade de raciocínio, embora num nível básico. Nesta concepção, o que chamamos de cognição, racionalidade ou inteligência é dado pela habilidade de processar informações, de forma a se adaptar às situações do ambiente e resolver problemas".

${ }^{4}$ Conforme Gordilho (2008, p. 54), a autoconsciência "é a noção que um indivíduo possui de si próprio como sujeito de experiências e de outros estados mentais que ocorrem ao longo do tempo". Para comprovar que alguns animais não-humanos possuem autoconsciência, Gordilho cita o estudo realizado pelo cientista Gordon Gallup Junior, que desenvolveu um teste de reconhecimento audiovisual, e deu aos chimpanzés uma oportunidade de eles se familiarizem com sua própria imagem em espelhos, para em seguida anestesiar esses animais. Enquanto estavam inconscientes, as suas sobrancelhas e ouvidos foram marcados com pontos vermelhos, sem cheiro ou sabor. Os chimpanzés quando se acordaram e viram-se no espelho, tocavam nos pontos vermelhos, reconhecendo a sua própria imagem. Até então, nenhuma criança com menos de 5 (cinco) anos de idade havia passado nesse teste de autorreconhecimento no espelho.

5 De acordo com Regan (2006), os mamíferos e as aves possuem consciência daquilo que está acontecendo ao seu redor e também quando acontece algo consigo mesmos. Assim, esses animais sabem quando há uma interferência em seu próprio corpo, de modo que eles possuem interesse nessas intervenções, independentemente de outros não atribuírem importância a esse fato.

6 A teoria ética defendida por Peter Singer baseia-se no princípio da igual consideração de interesses, ou seja, para estabelecer se uma determinada ação é ética ou não, deve-se considerar de modo igual interesses semelhantes. Nessa perspectiva, os seres que podem ser considerados nessa teoria são todos aqueles que possuem alguma espécie de

Revista de Direito Brasileira | São Paulo, SP | v. 16 | n. 7 | p. 304 - 323 | Jan./Abr. 2017
} 
O conhecimento desses fatos propiciou uma releitura do tratamento conferido aos animais não-humanos pelos animais humanos. Dessa forma, não é mais possível defender um tratamento aos animais não-humanos enquanto coisas ou instrumentalizá-los como se fossem meios para o alcance de finalidades humanas, conforme acreditava Immanuel Kant (GORDILHO, 2008).

A mudança de perspectiva na consideração dos animais não-humanos pelos animais humanos, por sua vez, pode ser fomentada através do ordenamento jurídico. Afinal, o Direito, como instrumento de controle social, é capaz de provocar alterações nas relações entre o ser humano e os demais seres.

No caso brasileiro, Natália Luiza Alves Martins (2012) afirma que as primeiras normas de proteção aos animais não-humanos emanaram das Ordenações Afonsinas de 1446. Essas eram uma coleção de leis do Reino de Portugal que foram aplicadas no Brasil no período colonial. Em seu texto, havia a previsão de equiparação do furto de ave a qualquer outro tipo de furto (DOMINGUES, 2008).

Posteriormente, as Ordenações Afonsinas foram substituídas pelas Ordenações Manuelinas de 1521 (MARTINS, 2012). Essas, por sua vez, trouxeram norma que proibia a caça de lobos, perdizes e coelhos com instrumentos capazes de provocar sofrimento nesses animais ${ }^{8}$. Todavia, as Ordenações Manuelinas sofreram uma reforma durante o período da União Ibérica, que resultou nas Ordenações Filipinas. Em seu compilado de leis, no título LXXXVIII, que tratava "das caças e pescarias defezas [sic]", ficou expressamente proibido que as pessoas, em qualquer tempo do ano, jogassem materiais capazes de causar a morte dos peixes nos rios e lagos (PORTUGAL, 1870).

Nessa perspectiva, Martins (2012) declara que essas foram as primeiras normas protecionistas aos animais não-humanos em vigor no Brasil, embora seus fundamentos estivessem relacionados a questões econômicas e patrimoniais.

Por outro lado, para Laerte Levai (2012), as primeiras normas com o objetivo de proteger os animais não-humanos surgiram com o advento da Lei $n^{\circ} 183$, de 9 de outubro de 1895, durante o Brasil Império. Essa lei estabeleceu o Código de Postura do município de São Paulo. Seu propósito era proibir todos os atos que caracterizassem maus-tratos, abusos, crueldade com os animais não-humanos ou a destruição inútil desses seres.

Para o autor, ela rompeu com o absoluto silêncio em relação aos animais que perdurava no território brasileiro, sendo pioneira no reconhecimento dos animais enquanto seres sencientes, assim como representou "a gênese da legislação animal que surgiria no século seguinte" (LEVAI, 2012, p. 180).

O período imperial ainda foi marcado pela primeira constituição brasileira: a Constituição Política do Imperio do Brazil de 1824. Contudo, em seu texto normativo, não houve nenhuma referência à fauna ou aos animais não-humanos. Aliás, a mesma situação pode ser observada na primeira constituição republicana brasileira: a Constituição da República dos Estados Unidos do Brasil de 1891.

Somente com a Constituição da República dos Estados Unidos do Brasil de 1934, passa a existir norma constitucional acerca dos animais não-humanos devido ao artigo $5^{\circ}$, inciso XIX, alínea "j", que dispôs sobre a competência privativa da União em legislar sobre "bens do

interesse, sendo que os animais não-humanos por serem seres sencientes possuem um interesse básico, que é o interesse em não sofrer (SINGER, 2013).

7 Gordilho (2008) apresenta o exemplo da chimpanzé Washoe, que foi criada como uma criança surda-muda por cientistas, de modo que lhe foi ensinado a linguagem dos sinais. Washoe não somente aprendeu essa língua, como também a ensinou a seu filhote chamado Loulis. Ademais, os cientistas registraram horas de conversas entre Washoe, Loulis e outros chimpanzés sob os mais variados assuntos como brincadeiras e disciplina.

${ }^{8}$ No Livro V, Título LXXXIIII, página 252, das Ordenações Manuelinas, lê-se que: “que nom cacem perdizes, nem lebres, nem coelhos com boi, redes, nem fio". Disponível em: <http://www1.ci.uc.pt/ihti/proj/manuelinas/15p252.htm>. Acesso em: 19 out. 2016.

Revista de Direito Brasileira | São Paulo, SP | v. 16 | n. 7 | p. 304 - 323 | Jan./Abr. 2017 
domínio federal, riquezas do subsolo, mineração, metalurgia, águas, energia hidrelétrica, florestas, caça e pesca e a sua exploração". Todavia, Fernanda Fontoura Medeiros compreende que essa ampliação obedeceu a um recorte extremamente antropocêntrico", pois "a preocupação atinente aos bens ambientais pendia muito mais para o quesito econômico do que propriamente para o ambiente per si" (MEDEIROS, 2013, p.47).

Ainda durante a primeira metade do século XX, entrou em vigor, no Brasil, o Decreto $\mathrm{n}^{\circ}$ 24.645 de 1934. Para Edna Cardoso Dias (2014), essa foi a primeira legislação que rompeu com o caráter antropocêntrico do ordenamento jurídico brasileiro. Esse decreto afirmava a tutela jurídica dos animais não-humanos através de representação pelo Ministério Público, definia o que consistia em maus-tratos com os animais e regulamentava a utilização de transportes com tração animal. Desse modo, ele representou um avanço para a proteção dos animais não-humanos ${ }^{10^{3}}$ no país.

Embora o número de legislações acerca do bem-estar animal tenha aumentado durante o Século XX, no plano constitucional, os animais não-humanos ainda não encontravam seu devido amparo.

Após a Constituição de 1934, o Brasil ainda teve mais quatro constituições ${ }^{11}$. De acordo com Medeiros (2013), as constituições brasileiras referentes aos anos de 1937, 1946 e 1967 trataram dos animais não-humanos sob uma ótica econômica. Todavia, a crise ambiental acirrada após a Segunda Guerra Mundial, a Conferência de Estocolmo em 1972 e a percepção de que os recursos ambientais são limitados provocou a constitucionalização do ambiente e a ecologização da Constituição, que se refletiu na Constituição da República Federativa do Brasil de 1988 (BENJAMIN, 2011).

Nessa perspectiva, o Texto Fundamental de 1988 abordou a proteção ambiental em suas normas. Desse modo, o Capítulo VI, artigo 225 trata especificamente dos recursos naturais como o solo, a água, a mineração, assim como a flora e a fauna, sendo que, nesse último item, atentouse para a situação dos animais não-humanos.

Ademais, a Constituição da República Federativa do Brasil de 1988 estabeleceu os direitos fundamentais em seu artigo $5^{\circ}$, ou seja, direitos que são inalienáveis, imprescritíveis e irrenunciáveis (SILVA, 2005) e que são essenciais para garantir a dignidade da pessoa humana (SARLET, 2003).

Embora o constituinte tenha elencado um catálogo de direitos fundamentais, Ingo Sarlet (2003) afirma que existem direitos fundamentais em outras partes do texto constitucional. No caso do artigo 225, é possível considerá-lo um direito fundamental, uma vez que a própria Constituição afirma a sua necessidade para uma sadia qualidade de vida, de modo que ele constitua um pressuposto para o alcance da dignidade da pessoa humana. Nesse sentido, Tiago Fensterseiffer (2008) defende inclusive uma dimensão ecológica da dignidade humana.

\footnotetext{
9 "Denomina-se antropocentrismo o sistema filosófico que pôs o homem no centro do universo, concepção essa que nos atribuiu - em nome da supremacia da razão - o poder de dominar a natureza e os animais. $\mathrm{O}$ termo, originário do grego (homem) e do latim (centrum), relaciona-se à ideia religiosa da essência divina do ser humano" (LEVAI, 2006, p. 172).

${ }^{10}$ Há divergências na doutrina acerca da vigência do Decreto $\mathrm{n}^{\circ} 24.645$ de 1934. Esse decreto foi publicado durante o Governo Provisório de Getúlio Vargas, sendo que nesse período, o Poder Executivo exercia as funções do Poder Legislativo, de acordo com o art. $1^{\circ}$ do Decreto ${ }^{\circ} 19.398$ de 1930. Dessa forma, o Decreto $\mathrm{n}^{\circ} 24.645$ de 1934 teria força de lei, não podendo ser revogado por outro decreto. Todavia, a doutrina majoritária considera que esse decreto foi revogado pelo advento do Decreto Federal no 11 de 18 de janeiro de 1991 (CASTRO, 2006).

${ }^{11}$ Em 1969, entrou em vigor a Emenda Constitucional $\mathrm{n}^{\circ} 1$. Para parte da doutrina, tratou-se de uma nova constituição, embora tivesse recebido o nome de emenda. Nesse sentido, José Afonso da Silva (2005, p.87, grifos do autor) afirma que: "Teórica e tecnicamente, não se tratou de emenda, mas de nova constituição. A emenda só serviu como mecanismo de outorga, uma vez que verdadeiramente se promulgou texto integralmente reformulado, a começar pela denominação que se lhe deu: Constituição da República Federativa do Brasil enquanto a de 1967 se chamava apenas Constituição do Brasil".
} 
O artigo 225, por sua vez, foi responsável por desvincular a proteção dos animais nãohumanos de uma ótica econômica por anunciar em seu $\S 1^{\circ}$, inciso VII que incumbe ao Poder Público "proteger a fauna e a flora, vedadas, na forma da lei, as práticas que coloquem em risco sua função ecológica, provoquem a extinção de espécies ou submetam os animais a crueldade" (BRASIL, 1988).

Dessa forma, essa norma constitucional trouxe uma nova perspectiva para a compreensão jurídica acerca dos animais não-humanos, pois ao vedar as práticas que submetam os animais à crueldade, ela protegeu diretamente os animais não-humanos e demonstrou principalmente uma preocupação com a vida desses seres. Assim, evidencia-se o reconhecimento de um valor próprio desses animais. Afinal, os benefícios fornecidos aos animais humanos em decorrência dessa vedação são apenas incidentais.

Ainda cumpre ressaltar que, embora a preocupação com o sofrimento dos animais nãohumanos tenha aparecido na legislação brasileira desde o período colonial como sugere Martins (2012), essa é a primeira vez que uma norma protetiva dos animais não-humanos assume um caráter constitucional, sendo ainda considerada um direito fundamental.

Nessa perspectiva, é possível afirmar que o constituinte admitiu que os animais nãohumanos são seres sencientes, resguardou seu interesse em não sofrer, além de reconhecer um valor próprio a esses seres, uma vez que a sua proteção não corresponde a finalidades humanas, mas à preservação da integridade física e psíquica dos animais não-humanos.

Por isso, Antonio Herman Benjamin (2011) afirma que há o abandono da rigidez de uma visão antropocêntrica na Constituição Federal de 1988, ou seja, as normas constitucionais já não se destinam apenas a satisfazer os interesses dos seres humanos, uma vez que esses não são sempre o centro das preocupações constitucionais. Em sua perspectiva, a tutela ambiental gradual e erraticamente adota uma visão mais ampla, de caráter biocêntrico ${ }^{12}$ ou até mesmo econcêtrico ${ }^{13}$. Assim, "o paradigma do homem como prius é irreversivelmente trincado" (BENJAMIN, 2011, p. 131).

Já Tagore Trajano Silva (2015) afirma que há uma postura pós-humanista no artigo 225, $\S 1^{\circ}$, inciso VII da Constituição Federal de 1988, que possibilita que a interpretação e a aplicação do texto constitucional ultrapassem as fronteiras humanas. $\mathrm{O}$ autor ainda considera que a Constituição Federal de 1988 é "o marco para o pensamento sobre a dignidade animal, uma vez que ao proibir que o animal seja tratado de forma cruel, reconhece ao animal não-humano o direito de ter respeitado o seu valor intrínseco, sua integridade, vida e liberdade" (SILVA, 2009, p. 11141).

Ainda nesse sentido, Ingo Sarlet e Tiango Fensterseiffer (2008) afirmam que houve o reconhecimento por parte do constituinte do valor inerente a outras formas de vida não-humanas através do artigo 225, §1 $1^{\circ}$, inciso VII da Constituição Federal de 1988. Assim, o Texto Fundamental protege os animais não-humanos inclusive contra a ação humana, de modo que se torna evidente que a Constituição não buscou proteger apenas o ser humano, pelo menos de forma direta e em todos os casos, e também houve uma refutação de uma visão instrumental da vida animal (SARLET; FENSTERSEIFFER, 2008).

Dessa forma, a Constituição Federal de 1988 introduziu uma nova compreensão jurídica acerca dos animais não-humanos, em que é reconhecido o valor próprio desses seres. Todavia, a indefinição do conceito de "crueldade" restringe a efetividade dessa norma de acordo com o modo em que ela é interpretada. Por isso, insta a necessidade de ser analisado como os magistrados têm compreendido o que é crueldade com os animais não-humanos.

\footnotetext{
${ }^{12}$ Conforme Bahia (2006), o biocentrismo consiste na atribuição de dignidade a todos os seres vivos, de modo que os animais (humanos e não-humanos), assim como as plantas possuíssem um valor intrínseco.

${ }^{13} \mathrm{O}$ ecocentrismo atribui valor intrínseco à comunidade biótica e aos sistemas ecológicos. Assim, a natureza possui dignidade e o ser humano está compreendido na natureza (BAHIA, 2006).
}

Revista de Direito Brasileira | São Paulo, SP | v. 16 | n. 7 | p. 304 - 323 | Jan./Abr. 2017 


\section{A (IN)DEFINIÇÃO DO CONCEITO DE CRUELDADE PARA COM OS ANIMAIS NÃO-HUMANOS}

A Constituição da República Federativa do Brasil de 1988 destacou-se na proteção aos animais não-humanos pela vedação de práticas que submetam esses animais à crueldade em seu artigo $225, \S 1^{\circ}$, inciso VII, em comparação com as Constituições anteriores, que tratavam os animais não-humanos através de um viés econômico.

Todavia, a indefinição do que consiste a crueldade para com os animais não-humanos possibilita que sua interpretação apresente múltiplos significados, que podem não assegurar a efetiva proteção pretendida por aquela norma constitucional (SANTANA, 2008).

Por outro lado, Carlos Maximiliano (2006, p. 13) aponta que a palavra que forma uma norma jurídica "é por sua natureza elástica e dúctil, varia de significação com o transcorrer do tempo e a marcha da civilização". Essa elasticidade pode ser explicada inclusive pelo próprio caráter dinâmico do ordenamento jurídico, que sofre com as mudanças ocorridas no seio da sociedade, como as mudanças de ideologia, as alterações de valores e os avanços tecnológicos. Assim, a interpretação constitucional serve como um mecanismo para acompanhar o constante desenvolvimento e mutação da sociedade (BASTOS, MEYER-PFLUG, 2005).

Além de os conceitos jurídicos indeterminados favorecerem a adaptação à realidade histórica, eles também transferem parte da valoração jurídica do legislador para o intérprete, que seriam os magistrados (QUEIROZ, 2005).

No caso da vedação à crueldade para com os animais não-humanos, Patrícia Azeredo da Silveira (2008) afirma que os tribunais interpretam essa norma com base em um conteúdo casuístico, além de que a interpretação sofre limitações por questões culturais e até socioeconômicas. Dessa forma, algumas práticas que implicam em crueldade para com os animais não-humanos não são consideradas ilícitas.

Nessa perspectiva, apresenta-se um problema na definição de práticas cruéis para com os animais não-humanos, pois como atestam Celso Ribeiro Bastos e Samantha Meyer-Pflug (2005, p. 155), "entre a letra da lei e a concretude do ato de aplicação da norma constitucional existe a vontade do intérprete", 14 .

Dessa forma, torna-se necessário averiguar como o artigo $225, \S 1^{\circ}$, inciso VII da Constituição Federal tem sido interpretado. Para tanto, serão analisadas as decisões do Supremo Tribunal Federal (STF) que vedaram práticas consideradas cruéis para com os animais nãohumanos. A opção pelas decisões dessa corte decorre do fato de que ela é um dos principais órgãos jurisdicionais responsáveis por realizar o controle de constitucionalidade repressivo, difuso ou concentrado em decorrência de inconstitucionalidades materiais.

\subsection{A crueldade para com os animais não-humanos pela jurisprudência do Supremo Tribunal Federal}

A Constituição da República Federativa do Brasil de 1988 destaca-se pela sua supremacia no ordenamento jurídico brasileiro, sendo que as normas infraconstitucionais devem estar em conformidade e adequadas a lex legum. Em razão de sua relevância, insta a necessidade de um órgão jurisdicional zelar pelos seus dispositivos, por isso, o artigo 102, caput da Constituição atribuiu ao Supremo Tribunal Federal essa função.

\footnotetext{
${ }^{14}$ Cumpre ressaltar que o magistrado, ao adquirir o papel de intérprete das normas constitucionais, não pode aplicálas de acordo com a sua vontade e de forma irrestrita. A sua vontade deve ser limitada pela lógica, pelas regras da semântica e da sintaxe, pela tradição de sentidos (que não engessa, mas baliza, porque novos sentidos precisam ser justificados), pela coerência a outras normas e a outros valores presentes no ordenamento jurídico, pela construção democrática das normas e pela vedação do retrocesso.
} 
Ademais, de acordo com Zeno Veloso (2003), torna-se indispensável um mecanismo eficiente para garantir a unidade infra sistemática e eliminar os fatores de desagregação e ruptura na Constituição Federal. Nessa perspectiva, o autor designa o controle de constitucionalidade como o meio capaz de expungir as leis e atos normativos que se opõem ao Texto Fundamental, além de servir como uma barreira aos excessos, abusos e desvios de poder.

O controle de constitucionalidade, por sua vez, apresenta quatro modalidades, conforme Luís Roberto Barroso (2006). Assim, ele pode ser classificado de acordo com a natureza do órgão de controle em político ou judicial. No caso do controle político, cabe a um órgão desvinculado do Poder Judiciário exercer a função jurisdicional. Esse sistema é tipicamente francês. Já o controle judicial atribui a um órgão vinculado ao Poder Judiciário a competência do controle de constitucionalidade, sendo que a sua origem é estadunidense.

A segunda modalidade consiste no momento do exercício do controle de constitucionalidade, sendo que esse pode ser controle preventivo ou repressivo. No primeiro caso, o controle é exercido previamente à conversão de um projeto de lei em lei com o intuito de evitar a recepção de norma inconstitucional no ordenamento jurídico. Já o controle repressivo também é chamado de sucessivo ou a posteriori e ele é realizado quando a lei já está em vigor. Seu objetivo é interromper a eficácia de norma inconstitucional.

Quanto ao órgão judicial que exerce o controle, há o controle difuso e o controle concentrado. O controle difuso é exercido por todo e qualquer juiz ou tribunal, que pode não reconhecer a constitucionalidade de uma determinada lei e não a aplicar no caso concreto analisado. No controle concentrado, por sua vez, há apenas um órgão ou um número limitado de órgãos responsáveis por realizar o controle de constitucionalidade.

E a última modalidade indica a forma ou o modo de controle judicial, que pode ser controle por via incidental ou controle por via principal ou direta. No primeiro caso, a questão da constitucionalidade precisa ser decidida como premissa necessária para a resolução de determinado litígio. Já na segunda hipótese, a análise da constitucionalidade de uma lei ou ato normativo é o pedido da ação, sendo que não há lide em sentido técnico, nem partes. No Brasil, o controle por via incidental confunde-se com o controle difuso, e o controle por via principal com o controle concentrado.

Além dessas modalidades, Barroso (2006) faz uma distinção quanto às espécies de inconstitucionalidade, que podem ser formais ou materiais. Naquelas, há inobservância de regras necessárias para a edição da norma. Nessas, há uma incompatibilidade de conteúdo, substantiva, entre a lei ou ato normativo e a Constituição.

Diante do exposto, pode-se afirmar que, no Brasil, o controle de constitucionalidade é

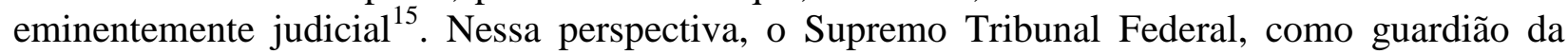
Constituição, realiza o controle repressivo, difuso/ via incidental, concentrado/ via principal e em decorrência de inconstitucionalidades formais e materiais. Em termos de controle difuso, a Suprema Corte pode atuar através de duas formas: no julgamento de causas de sua competência originária ou mediante recurso extraordinário.

No caso do recurso extraordinário, é necessário verificar o juízo de admissibilidade, ou seja, primeiramente, deve-se averiguar se há o preenchimento das hipóteses de cabimento e atendimento aos requisitos formais, de acordo com o artigo 102, inciso III da Constituição; em um segundo momento, deve-se apurar a existência de causas decididas em única ou última

\footnotetext{
${ }^{15}$ O constitucionalista Luís Roberto Barroso (2006, p. 43) ressalta que embora o controle de constitucionalidade brasileiro seja eminentemente de natureza judicial, "existem, no entanto, diversas instâncias de controle político de constitucionalidade, tanto no âmbito do Poder Executivo - e.g., o veto de uma lei por inconstitucionalidade - como no Poder Legislativo - e.g, rejeição de um projeto de lei pela Comissão de Constituição e Justiça da casa legislativa, por inconstitucionalidade".
} 
instância. Por fim, a Emenda Constitucional no 45/2004 determinou outro requisito necessário: a existência de repercussão geral ${ }^{16}$ das questões constitucionais discutidas no caso.

Em termos de controle concentrado, o Supremo Tribunal Federal é responsável por declarar a inconstitucionalidade de lei ou ato normativo federal ou estadual através da ação direta de inconstitucionalidade (ADIn), de acordo com o artigo 102, inciso I, alínea "a" da Constituição. Nessa ação, julga-se a validade de uma norma, in abstrato. Os efeitos dessa decisão são erga omnens, ou seja, são válidos para terceiros, não somente entre as partes do processo e, em regra, apresentam efeito ex tunc ${ }^{17}$, isto é, retroativos (VELOSO, 2003).

Ademais, o artigo 102, $\S 2^{\circ}$ da Carta Maior determina que essa decisão terá efeito vinculante em relação aos demais órgãos do Poder Judiciário e da Administração. Assim, nota-se que o Poder Legislativo ficou excluído do alcance do efeito vinculante ${ }^{18}$, de modo que é possível que o legislador provenha acerca da matéria considerada inconstitucional pela Suprema Corte (BARROSO, 2006).

No caso dos animais não-humanos, o Supremo Tribunal Federal, no exercício do controle de constitucionalidade, já emitiu decisões acerca da sua situação. A primeira decisão nesse sentido foi o Recurso Extraordinário n ${ }^{\circ}$ 153.531-8 de 1997 do Estado de Santa Catarina sobre a farra do boi.

De acordo com Carolina Bahia (2006), a farra do boi consiste em uma prática realizada, geralmente, durante a Semana Santa ou no período natalino no estado catarinense. Para a aquisição do boi, há o levantamento de verbas por parte de pessoas que se associam para a organização desse evento. $\mathrm{O}$ boi escolhido, por sua vez, deve ser bravo. No dia marcado para a farra, esse animal é recepcionado pela comunidade em um espaço previamente definido com foguetes e buzinas. Após a sua soltura, ele torna-se alvo de correrias, pegas, lides, provocações com gritos, varas e perseguições. O objetivo dessa prática é deixar o animal em fúria, de modo a provocar medo e tensão nos participantes. Quando o animal atinge a exaustação, ele é sacrificado para servir de alimento à comunidade.

Ao decidir sobre a incidência de crueldade para com os animais não-humanos na farra do boi, o ministro Francisco Rezek assinalou as dificuldades de se posicionar acerca desse tema em seu voto. Primeiramente, o ministro afirmou que é preciso resistir às sombras da metajuridicidade, que podem instigar questionamentos sobre o motivo de uma ação que visa a proteção dos animais não-humanos, quanto existem tantos dramas sociais. Em um segundo momento, é necessário afastar a indiferença quanto à sensibilidade dos animais.

\footnotetext{
${ }^{16}$ A Constituição Federal de 1988 não definiu o que é a repercussão geral. Todavia, a Lei no $11.418 / 06$ regulamenta os pontos centrais do mecanismo de repercussão geral e o Código de Processo Civil de 2015 afirma em seu art. 1.035 que " $\$ 1^{\circ}$ Para efeito de repercussão geral, será considerada a existência ou não de questões relevantes do ponto de vista econômico, político, social ou jurídico que ultrapassem os interesses subjetivos do processo. $\S 2^{\circ} \mathrm{O}$ recorrente deverá demonstrar a existência de repercussão geral para apreciação exclusiva pelo Supremo Tribunal Federal. $\S$ $3^{\circ}$ Haverá repercussão geral sempre que o recurso impugnar acórdão que: I - contrarie súmula ou jurisprudência dominante do Supremo Tribunal Federal; II - (revogado pela Lei n. 13.256, de 4-2-2016); III - tenha reconhecido a inconstitucionalidade de tratado ou lei federal, nos termos do art. 97 da Constituição Federal".

${ }^{17} \mathrm{O}$ art. 27 da Lei $\mathrm{n}^{\circ}$ 9.882/99 permite que, em razões de segurança jurídica ou excepcional interesse social e pelo voto da maioria de dois terços dos membros do Supremo Tribunal Federal, seja possível reformular os efeitos da decisão, para que sejam válidos somente a partir do trânsito em julgado ou de outro momento que venha a ser fixado. ${ }^{18} \mathrm{O}$ agravo regimental na reclamação no 13.019 do Distrito Federal firma esse entendimento: "O efeito vinculante e a eficácia contra todos ('erga omnes'), que qualificam os julgamentos que o Supremo Tribunal Federal profere em sede de controle normativo abstrato, incidem, unicamente, sobre os demais órgãos do Poder Judiciário e os do Poder Executivo, não se estendendo, porém, em tema de produção normativa, ao legislador, que pode, em consequência, dispor, em novo ato legislativo, sobre a mesma matéria versada em legislação anteriormente declarada inconstitucional pelo Supremo, ainda que no âmbito de processo de fiscalização concentrada de constitucionalidade, sem que tal conduta importe em desrespeito à autoridade das decisões do STF". Disponível em: < http://redir.stf.jus.br/paginadorpub/paginador.jsp?docTP=TP\&docID=5399923>. Acesso em: 03 nov. 2016.

Revista de Direito Brasileira | São Paulo, SP | v. 16 | n. 7 | p. 304 - 323 | Jan./Abr. 2017
} 
Dessa forma, é possível observar a complexidade do processo de interpretação da norma constitucional que veda a crueldade para com os animais não-humanos, pois o intérprete precisa desvincular-se de seus posicionamentos subjetivos para decidir de acordo com os interesses dos animais não-humanos. Por isso, enquanto a comunidade jurídica não se convencer que os animais não-humanos são sencientes e possuem interesses primários que devem ser respeitados, atos de crueldade continuarão a ser realizados e a força normativa da Constituição ficará prejudicada (BLANCO, 2013).

O ministro Francisco Rezek, por sua vez, ciente desses obstáculos, foi capaz de atentar para a situação dos animais não-humanos na farra do boi e considerá-la inconstitucional devido à crueldade imposta. Seu voto contrário à prática foi acompanhado pelos demais ministros, à exceção do Ministro Maurício Côrrea, que considerou a farra do boi uma manifestação cultural passível de proteção constitucional.

Em sua obra "Princípios da proporcionalidade nas manifestações culturais e na proteção da fauna", Carolina Bahia (2006) suscita importantes reflexões sobre esse recurso ${ }^{19}$. A autora questiona se o objetivo da decisão era a descaracterização cultural da comunidade que realizava a farra do boi, uma vez que essa prática era vista como um ato de selvageria, de fomento à violência, à transgressão sexual, em confronto com os valores da sociedade.

Nessa perspectiva, instala-se a discussão sobre se a crítica à farra do boi e a recepção judicial pela sua vedação corresponde mais a uma relação de preconceito para com um grupo do que realmente a uma consciência ética acerca dos animais não-humanos. Nesse sentido, Gary Francione sugere que as proibições de manifestações culturais cruéis para com os animais nãohumanos ocorrem porque essas "simplesmente não fazem parte das tradições de uma cultura em particular ou das tradições do grupo dominante em uma sociedade e, portanto, não fazem parte da exploração institucionalizada de animais dentro daquela cultura" (FRANCIONE, 2013, p. 271).

Cumpre ressaltar que ao fazer essa observação, Francione (2013) aponta que, nos Estados Unidos, há leis proibitivas das rinhas de animais, enquanto os rodeios não são vedados. Contudo, ambos visam ao entretenimento do público e ocasionam crueldade para com os animais não-humanos, só que as rinhas são práticas tipicamente associadas às "classes baixas", ao passo que os rodeios são tradicionalmente culturais e economicamente relevantes.

Essa análise, por sua vez, pode ser estendida à situação brasileira, pois o Supremo Tribunal Federal, na Ação Direita de Inconstitucionalidade (ADIn) n ${ }^{\circ} 1.856$ do Estado do Rio de Janeiro, julgou inconstitucional as rinhas de galo devido ao sofrimento imposto aos animais nãohumanos. Esse entendimento também está contido na ADIn no 3.776-5 do Estado do Rio Grande do Norte e na ADIn n ${ }^{\circ}$ 2.514-7 do Estado de Santa Catarina.

De acordo com Lília Maria Cadavez (2008), a rinha de galo demanda uma preparação prévia dos animais. Assim, ocorre o corte de cristas e barbelas dos galos geralmente sem anestesia. No dia da briga, seus bicos e esporas são reforçados com aço inoxidável e esses animais são colocados em uma arena, na qual devem brigar até que reste apenas um sobrevivente.

Além dessa prática cruel, recentemente, o Supremo Tribunal Federal também se posicionou contrário às vaquejadas na $\mathrm{ADIn} \mathrm{n}^{\circ} 4.983$ do Estado do Ceará. Essa prática consiste em uma corrida entre vaqueiros montados a cavalo com o intuito de derrubar um boi em fuga puxando-o pela sua cauda (BRASIL, 2016).

\footnotetext{
${ }^{19}$ A autora dedica-se principalmente em analisar o método utilizado pelos ministros para decidirem se a farra do boi consistia em crueldade para com os animais não-humanos. De acordo com a autora, a norma constitucional que veda a crueldade trata-se de um princípio, por isso os ministros deveriam ter realizado a ponderação de princípios para chegar em uma decisão. Em sentido contrário à Bahia (2006), Tagore Trajano Silva (2015) e Carolina Ferraz Passos (2015) consideram que aquela norma é uma regra.
} 
Entretanto, após pressão dos setores que se beneficiavam financeiramente com essa prática $^{20}$, em menos de um mês após a decisão da Suprema Corte, o Senado Federal aprovou projeto de $\mathrm{ei}^{21}$ que reconhece tanto as vaquejadas como os rodeios como patrimônio cultural imaterial do Brasil.

Dessa forma, procede a crítica proposta por Francione (2013). Afinal, nos casos expostos, observa-se que a norma constitucional que veda a crueldade para com os animais nãohumanos é aplicada de acordo com o fim em que os animais são utilizados e por quem os utiliza. No caso da farra do boi e da rinha de galo, práticas realizadas por minorias sociais que confrontam os valores da sociedade, a norma anticrueldade é considerada. Todavia, no caso das vaquejadas, em que o emprego dos animais implica lucratividade para determinados setores, essa norma é afastada.

Assim, observa-se um critério antropocêntrico e discricionário na interpretação do artigo 225, §1 $1^{\circ}$, inciso VII da Constituição Federal. Consequentemente, há uma aplicação discriminatória dessa norma constitucional, uma vez que não ela é aplicada de modo igual em casos semelhantes. Esse caráter arbitrário decorre de uma valorização por parte do intérprete dos interesses econômicos em detrimento da integridade física e psíquica dos animais não-humanos. Todavia, a própria Carta Maior em seu artigo 170, inciso VI determina que a ordem econômica deve respeitar as normas ambientais, inclusive mediante tratamento diferenciado. Assim, o poder econômico não pode ser invocado como justificativa para tolerar a crueldade para com os animais não-humanos.

Além disso, na decisão proferida pelo Supremo Tribunal Federal na ADIn n ${ }^{\circ} 1.856$ do Estado do Rio de Janeiro, atenta-se para os posicionamentos especistas ${ }^{22}$ dos ministros. Nesse sentido, observa-se o voto do ministro Celso de Mello:

O ordenamento constitucional brasileiro, para conferir efetividade e proteger a integridade do direito fundamental ao meio ambiente ecologicamente equilibrado, visando, com tais objetivos, neutralizar o surgimento de conflitos intergeneracionais, impôs, ao Poder Público, dentre outras medidas essenciais, a obrigação de proteger a fauna, vedadas, para tanto, práticas que coloquem em risco sua função ecológica ou que provoquem a extinção de espécies ou, ainda, que submetam os animais a atos de crueldade (BRASIL, 2011, p. 302, grifos do autor).

Portanto, o ministro alega que a vedação de práticas cruéis aos animais não-humanos visa a impedir conflitos intergeneracionais, ou seja, a proteção aos animais não-humanos disposta na Constituição, na verdade, objetivaria proteger as futuras gerações, não os próprios animais

\footnotetext{
${ }^{20}$ No dia 25 de outubro, em Brasília, ocorreu uma manifestação em favor da vaquejada, que reuniu cinco mil vaqueiros com carros de som e cerca de 1.500 cavalos. As associações dos vaqueiros presentes no ato alegavam que o fim da vaquejada causaria problemas para economia e resultaria no desemprego de mais de 700 mil pessoas. Essas manifestações também se repetiram em mais noves estados brasileiros. Disponível em: $<$ http://www1.folha.uol.com.br/cotidiano/2016/10/1825892-associacoes-divulgam-manifesto-a-favor-da-vaquejadae-propoem-dialogo.shtml>. Acesso em: 04 nov. 2016.

${ }^{21}$ O STF decidiu pela procedência da ADIn n 4.983 do Estado do Ceará no dia 06 de outubro de 2016 . No dia $1^{\circ}$ de outubro desse ano, o Senado Federal aprovou o Projeto de Lei da Câmara n ${ }^{\circ} 24 / 2016$, que reconhece os rodeios e as vaquejadas como patrimônio cultural imaterial brasileiro, sob a alegação de que a prática é uma tradição secular e apresenta importância para a economia regional nordestina. O projeto aguarda a sanção presidencial. Disponível em: <http://www12.senado.leg.br/noticias/materias/2016/11/01/projeto-que-da-a-vaquejada-status-de-patrimoniocultural-imaterial-vai-a-sancao>. Acesso em: 04 nov. 2016.

${ }^{22} \mathrm{O}$ termo especismo foi cunhado por Richard Ryder que o utilizou pela primeira vez em um panfleto contra a experimentação animal em 1970 (GORDILHHO, 2008). Ele consiste na prevalência da consideração dos interesses dos membros de uma espécie em detrimento de outra. Posteriormente, o termo tornou-se notório com o seu emprego pelo filósofo Peter Singer em seu livro "Libertação Animal".
} 
não-humanos. Assim, o ministro não atenta para o valor do animal em si, nem considera seu interesse em não sofrer, apenas defende os interesses da sua própria espécie.

Ainda é possível notar um argumento especista no esclarecimento realizado pelo ministro Cezar Peluso. Esse acredita que a imposição de crueldade com os animais não-humanos fere o princípio da dignidade da pessoa humana, uma vez a prática "implica, de certo modo, um estímulo às pulsões mais primitivas e irracionais do ser humano” (BRASIL, 2011, p.336).

Sua reflexão, por sua vez, é acompanhada pelo ministro Ricardo Lewandowski, que alega que o motivo de a Europa estar preocupada com o tratamento desumano, cruel e degradante que é fornecido aos animais destinados a testes em cosméticos, abatedouros e criadouros é que "quando se trata cruelmente ou de forma degradante um animal, na verdade está se ofendendo o próprio cerne da dignidade humana" (BRASIL, 2011, p. 336).

Esses argumentos são eivados de especismo na medida em que fundamentam uma norma de proteção aos animais não-humanos e que prima pela sua vida através de uma preocupação com o ser humano. Mais uma vez, os ministros atentam para a sua própria espécie e ignoram que o principal interessado em não sofrer com a crueldade é o próprio animal como ser senciente.

Nessa perspectiva, Erika Bechara (2003) afirma que a vedação constitucional de crueldade para com os animais não-humanos não se destina à proteção da integridade físicopsíquica desses seres, sendo que o sujeito passivo seria a coletividade. A autora ainda afirma que o artigo 225, $\S 1^{\circ}$, inciso VII do Texto Maior quando se refere à crueldade, compreende a submissão do animal a um mal além do absolutamente necessário, pois a legislação brasileira é permissiva na utilização dos animais não-humanos em casos que impliquem em sofrimento. Citase, como exemplo dessa hipótese, o artigo $32, \S 1^{\circ}$ da Lei $n^{\circ} 9.605 / 1988$ que permite a experiência dolorosa ou cruel em animal vivo quando não há recursos alternativos.

Todavia, o critério apontado pela autora obedece a uma lógica especista, porque a definição de crueldade depende do fim em que o animal não-humano é utilizado. Portanto, não se define crueldade de acordo com o sofrimento imposto ao animal, mas sim conforme os benefícios provocados ao ser humano, de modo que os interesses da espécie humana prevalecem sobre o interesse de qualquer outra espécie. Ademais, o seu argumento acarreta uma inversão da hierarquia das normas, pois a autora utiliza uma norma infraconstitucional permissiva para justificar uma interpretação restritiva à Constituição, quando, na verdade, é a norma constitucional que irradia efeitos sobre toda e qualquer norma infraconstitucional.

O problema é que o especismo não pode ser mais a base argumentativa para a aplicação do texto constitucional, porque é inconsistente e fundado em premissas falsas, além de que é notório o conhecimento de que os animais não-humanos possuem senciência e, portanto, têm interesse em não sofrer. Ademais, a perspectiva antropocêntrica não pode mais ser sustentada, uma vez que o animal humano não é o único ser que habita o planeta e que precisa da natureza para garantir a sua sobrevivência, sendo que essa não existe para a sua disposição. Portanto, torna-se necessário uma releitura da norma constitucional que veda a crueldade para com os animais não-humanos, de modo a considerar o valor do animal em si.

\section{CONSEQUÊNCIAS DE UMA RELEITURA DO ARTIGO 225, §1, INCISO VII DA CONSTITUIÇÃO FEDERAL DE 1988 SOB UMA ÉTICA ANIMALISTA}

Uma releitura do artigo 225, §1º inciso VII da Constituição Federal de 1988 é uma medida necessária, pois as interpretações realizadas pelos magistrados em decorrência dessa norma constitucional ainda sustentam uma visão antropocêntrica e especista. Todavia, essas perspectivas são inadmissíveis, pois os avanços científicos impossibilitam a crença de que a natureza existe a serviço da humanidade, de modo que os animais humanos podem dispor da vida dos demais seres.

Revista de Direito Brasileira | São Paulo, SP | v. 16 | n. 7 | p. 304 - 323 | Jan./Abr. 2017 
Portanto, forma-se o desafio de romper com o paradigma antropocêntrico no ordenamento jurídico brasileiro e empregar uma interpretação constitucional que realize uma consideração ética acerca dos animais não-humanos e afaste as discricionariedades na aplicação do artigo 225, $\S 1^{\circ}$, inciso VII da Carta Maior.

Nessa perspectiva, o filósofo estadunidense Tom Regan desenvolve uma teoria ética acerca dos animais não-humanos, em que esses seres são pensados a partir de si mesmos, não em razão dos interesses humanos. Essa teoria apresenta uma abordagem deontológica, ou seja, a ação moral é determinada independente da sua consequência, mas pela ação em si (NACONECY, 2006). Dessa forma, não se analisam os benefícios e prejuízos transcorridos de uma conduta para aferir sua moralidade.

O campo de consideração da teoria ética reganiana é restrita àqueles que são detentores de direitos morais ${ }^{23}$, ou seja, aqueles que possuem o direito de que ninguém interfira em sua vida, no seu corpo ou na sua liberdade (REGAN, 2006).

Os portadores de direitos morais são considerados sujeitos morais, ou seja, todos aqueles indivíduos que possuem interesses que devem ser considerados pelos seres humanos ao praticar uma ação, além de que o comportamento humano deve, em alguma medida, ser respeitoso para com os interesses desses indivíduos (CARDOSO, 2013).

Os sujeitos morais podem ser divididos em duas categorias: agentes morais e pacientes morais. Os primeiros consistem nos indivíduos que possuem capacidade de compreender as regras e comportar-se de acordo com elas, de modo que eles são moralmente responsáveis por suas atitudes. Já os pacientes morais não possuem capacidade de agir de acordo com os ditames morais, todavia eles sofrem com os atos praticados pelos agentes, por isso esses devem considerá-los em suas ações (REGAN, 2004).

Algumas teorias éticas cuidam apenas dos agentes morais. Contudo, esse posicionamento implicaria inclusive na desconsideração das crianças e dos absolutamente incapazes, por exemplo, de uma abordagem ética, já que esses são pacientes morais. Por outro lado, uma teoria ética que inclua esses indivíduos e exclua os animais não-humanos obedece uma lógica especista. Afinal, os animais como seres sencientes, com uma integridade física e psíquica, interessados naquilo que acontece com seus corpos e conscientes da sua existência, também são afetados pelos danos ou benefícios decorrentes das ações praticadas pelos agentes morais. Por isso, não há razão eticamente aceitável para a exclusão desses seres.

Nessa perspectiva, para Regan (2001), os animais não-humanos são considerados como pacientes morais, porque se assemelham aos animais humanos devido à "presença psicológica unificada", isto é, possuem sensibilidade, assim como capacidade cognitiva e volitiva. Ademais, na terminologia empregada pelo autor, todos os seres que possuem esses atributos podem ser chamados de "sujeitos-de-uma-vida".

Todo sujeito-de-uma-vida, por sua vez, possui um direito moral básico: o direito de ser tratado com respeito. Assim, esses indivíduos não podem ser considerados coisas ou meros recursos, mas constituem fins em si mesmos. (REGAN, 2004). Consequentemente, não é justificável a utilização desses seres para satisfazer os interesses de outros, mesmo que o seu emprego implique em amplos benefícios a quem os quer utilizar. Por isso, Regan reconhece um valor inerente $^{24}$ a todo o sujeito-de-uma-vida, ou seja, um valor em si, que afasta a possibilidade

\footnotetext{
${ }^{23}$ O filósofo Carlos Naconecy (2006) diferencia direitos legais de direitos morais. A primeira espécie de direito tratase dos direitos reconhecidos pelos governantes de uma sociedade e dispostos em uma legislação. Já a segunda seria o direito que algo ou alguém tem ou deveria ter por simplesmente ser o que é. Nessa perspectiva, o autor coloca que o animal tem um direito moral à vida, embora esse direito não seja reconhecido em termos legais.

${ }^{24}$ Cumpre ressaltar que o conceito de valor inerente difere do conceito de valor intrínseco na concepção de Regan. De acordo com Sônia Felipe (2006), o valor intrínseco é determinado conforme a capacidade de o animal nãohumano em sentir dor, prazer, bem-estar e mal-estar. Contudo, para Regan, o critério do valor intrínseco trata o animal não-humano como um receptáculo de sensações, sendo que seriam as experiências vividas que importariam para uma avaliação moral. Assim, "se o único problema ético fosse este: não causar dor, a moralidade humana
} 
de sua instrumentalização, um valor igual para todos que o possuem, independente das suas diferenças.

O conceito de valor inerente também enseja a compreensão de que o tratamento respeitoso devido aos animais não-humanos ocorre por um dever direto para com esses seres. Logo, a proteção dos animais não-humanos não advém de razões supervenientes, mas é devida pelos direitos morais dos animais não-humanos em desfrutarem de sua vida com integridade física e psíquica e em estado de liberdade.

Portanto, a partir da teoria reganiana, é possível compreender a vedação constitucional à extinção das espécies e a submissão dos animais não-humanos a crueldade como um dever direto de proteção a esses seres. Afinal, o constituinte garantiu a vida e a integridade desses animais ${ }^{25}$ (CARDOSO; TRINDADE, 2013).

Assim, o objetivo daquela norma constitucional não seria a prevenção de sentimentos cruéis no ser humano que podem posteriormente repercutir em outros humanos, nem a garantia de um meio ambiente ecologicamente equilibrado às futuras gerações humanas, porque o dever de tratar os animais de forma ética não sucede do interesse humano, mas deve ser cumprido simplesmente porque é o correto a fazer (NACONECY, 2006).

Ademais, Regan (2001) afirma que, historicamente, as leis que vedam a crueldade para com os animais não-humanos equivalem à proibição de um sofrimento desnecessário ou injustificado. Todavia, essas concepções estão de acordo com a visão dos animais humanos, pois é conforme seus interesses que será determinado se uma ação é cruel ou não. Esse critério de justificação ou necessidade, por sua vez, obedece a uma lógica antropocêntrica, pois ignora-se a situação do próprio animal e preza-se pelos benefícios proporcionados aos humanos.

Nessa perspectiva, o conceito de crueldade poderia ser reformulado a partir da compreensão de que os animais possuem um valor inerente, ou seja, constituem um fim em si mesmos. Portanto, eles não devem ser utilizados como meros recursos, mesmo quando o seu sofrimento fosse caracterizado como necessário ou justificado para acarretar benefícios aos humanos. Dessa maneira, a aplicação do artigo 225, $\S 1^{\circ}$, inciso VII da Carta Maior estaria isenta de critérios discricionários e, finalmente, o animal não-humano seria respeitado em sua individualidade e pela sua capacidade de sofrer (LEVAI, 2006).

\section{CONCLUSÃO}

Os avanços científicos indicaram que os animais não-humanos possuem capacidade de sentir dor ou prazer, autoconsciência, interesses e inclusive são hábeis para aprender e utilizar uma linguagem complexa. Nessa perspectiva, ocorreu a necessidade de revisar o tratamento conferido a esses seres pelos animais humanos e de afastar uma abordagem econômica desses seres no ordenamento jurídico brasileiro.

Enquanto é possível encontrar normas infraconstitucionais protetivas aos animais nãohumanos desde o período do Brasil Colonial, somente com a Constituição da República Federativa do Brasil de 1988, esses seres adquiriram uma proteção constitucional e tiveram seu valor próprio reconhecido no artigo $225, \S 1^{\circ}$, inciso VII do Texto Fundamental.

poderia ser plenamente alcançada com o emprego da analgesia” (FELIPE, 2006, p. 131), o que não é o caso. Portanto, o valor inerente resulta da peculiaridade da própria forma de vida.

${ }^{25}$ Acerca da existência de um dever direto no art. 225, $\$ 1^{\circ}$, inciso VII da Constituição Federal de 1988 , e no art. 32 da Lei n ${ }^{\circ}$ 9.605/1998 (Lei dos Crimes ambientais), Waleska Cardoso e Gabriel Trindade (2013, p. 211) afirmam que essas normas "acaso tivessem apenas o intuito de proteger os animais indiretamente, deveria ter outra redação, vedariam tratamentos cruéis contra os animais apenas quando terceiros pudessem testemunhar ou tomar conhecimento. Entretanto, a redação coíbe a crueldade em toda e qualquer circunstância, mesmo quando ninguém mais, além do agressor, tiver ciência do crime. O interesse normativo é inequívoco, qual seja proteger a integridade física e psicológica do animal, pelo fato de ele ser senciente, passível de sofrimento - o qual se quer evitar".

Revista de Direito Brasileira | São Paulo, SP | v. 16 | n. 7 | p. 304 - 323 | Jan./Abr. 2017 
Essa norma constitucional representou um avanço para a compreensão jurídica acerca dos animais não-humanos. Ademais, ao tratar da crueldade para com os animais não-humanos, o constituinte utilizou uma expressão vaga que precisa ser definida pelo intérprete. Essa abertura, por sua vez, possibilita que a norma constitucional seja atualizada conforme a evolução histórica e o desenvolvimento de novos valores na sociedade.

Todavia, os magistrados aplicam essa norma com base em uma lógica antropocêntrica e especista, conforme observado nas decisões proferidas pelo Supremo Tribunal Federal em sede de controle de constitucionalidade, de modo a comprometer a sua efetividade.

Nesse sentido, a Suprema Corte alega que o objetivo do artigo $225, \S 1^{\circ}$, inciso VII da Carta Maior é preservar o ser humano de atitudes cruéis, que podem posteriormente repercutirem contra os seres humanos ou ainda que a proteção aos animais não-humanos ocorre para garantir um meio ambiente ecologicamente equilibrado às futuras gerações humanas. Portanto, o Supremo não admite que o principal interessado e protegido pela vedação da crueldade para com os animais não-humanos são os próprios animais que sofrem com essa prática.

Esses fundamentos, por sua vez, são inadmissíveis, uma vez que os seres humanos não constituem a razão da existência dos demais seres e do meio ambiente, portanto, eles não podem dispor da natureza e de seus elementos como se fossem legitimados a dominá-los. Aliás, o notório conhecimento de que os animais não-humanos possuem senciência, interesse e consciência daquilo que interfere em sua vida, corpo e liberdade, torna insustentável o argumento de que a sua proteção ocorre por motivos supervenientes. Por isso, insta a necessidade de uma releitura da norma constitucional que veda a crueldade para com os animais não-humanos.

Assim, propõe-se uma interpretação constitucional sob uma ética animalista elaborada por Tom Regan, uma vez que esse filósofo realizou uma consideração ética acerca dos animais não-humanos, pensando propriamente nesses seres, não nos interesses humanos.

A teoria ética reganiana é aplicada aos sujeitos morais, que podem ser tanto agentes morais como pacientes morais. Os primeiros são indivíduos que compreendem os ditames morais e são responsáveis pelas suas ações. Já os segundos consistem em indivíduos que não são capazes de agir conforme os ditames morais, por isso não são responsabilizados pelos seus atos, contudo eles são afetados pelas ações praticadas pelos agentes morais. Na segunda categoria, Regan inclui os animais não-humanos.

Todavia, não é todo e qualquer animal não-humano que pode ser considerado um paciente moral. Apenas os animais que possuem sensibilidade, capacidade cognitiva e volitiva que podem ser considerados na teoria ética reganiana. Aliás, todos os seres que possuem esses atributos são denominados sujeitos-de-uma-vida.

Esses seres, por sua vez, possuem um valor inerente, que afasta a possibilidade de sua instrumentalização. Ademais, desfrutam de um direito moral básico de serem tratados com respeito, de modo que a sua proteção pelos animais humanos ocorre por um dever direto.

Nessa perspectiva, a aplicação da teoria ética reganiana para uma interpretação do artigo 225, §1 ${ }^{\circ}$, inciso VII da Constituição Federal de 1988, resultaria nas seguintes consequências:

1) Admissão de um dever direto de proteção aos animais não-humanos. Dessa forma, a justificativa para a aplicação da norma constitucional seria a garantia da integridade física e psíquica do animal não-humano, de modo que as repercussões dessa norma para os seres humanos seriam consideradas apenas benefícios incidentais.

2) Identificação de um valor inerente aos animais não-humanos. Consequentemente, não haveria a possibilidade da utilização desses seres como coisas ou meros recursos para satisfazer os interesses dos animais humanos, mesmo quando o seu emprego resultasse em amplos benefícios aos humanos. Aliás, a compreensão de que os animais não-humanos possuem um valor próprio implicaria uma nova compreensão sobre a possibilidade de imposição de sofrimento a esses seres. Assim, a necessidade de inflição de dor seria medida de acordo com o benefício proporcionado ao próprio animal com o intuito de livrá-lo de um sofrimento maior, por 
exemplo, no caso da realização de um tratamento de saúde que cause algum mal ao animal a fim de salvar a sua vida. Logo, não seria mais aceitável definir o conceito de crueldade com base nos interesses humanos.

3) A existência de um direito moral básico de tratar os animais não-humanos com respeito disposto nessa norma constitucional ensejaria a compreensão de que esses animais possuem direitos reconhecidos indiretamente no texto constitucional.

Diante do exposto, é possível uma interpretação constitucional do artigo $225, \S 1^{\circ}$, inciso VII da Constituição Federal de 1988 que reconheça os direitos animais. Para tanto, insta a necessidade de uma ruptura com o paradigma antropocêntrico e especista na aplicação dessa norma, de modo a consolidar um tratamento jurídico dos animais não-humanos que preze pelo seu valor próprio.

\section{REFERÊNCIAS}

BAHIA, Carolina Medeiros. Princípio da proporcionalidade nas manifestações culturais e na proteção da fauna. Curitiba: Juruá, 2006.

BARROSO, Luís Roberto. O controle de constitucionalidade no Direito brasileiro: exposição sistemática da doutrina e análise crítica da jurisprudência. São Paulo: Saraiva, 2006.

BASTOS, Celso Ribeiro; MEYER-PFLUG, Samantha. A interpretação como fator de desenvolvimento e atualização das normas constitucionais. In: SILVA, Virgílio Afonso da (org.). Interpretação constitucional. São Paulo: Malheiros Editores, 2005. p. 145-164.

BECHARA, Erika. A proteção da fauna sob a ótica constitucional. São Paulo: Juarez de Oliveira, 2003.

BENJAMIN, Antonio Herman. A constitucionalização do ambiente e ecologização da Constituição brasileira. In: CANOTILHO, José Joaquim Gomes; LEITE, José Rubens Morato (org.). Direito constitucional ambiental brasileiro. 4. ed. São Paulo: Saraiva, 2011. p. 77-150.

BLANCO, Carolina Souza Torres. O enquadramento constitucional dos animais não humanos. Revista Brasileira de Direito Animal, Salvador, v. 8, n. 12, p.75-94, jan./abr. 2013. Disponível em: <http://www.portalseer.ufba.br/index.php/RBDA/article/view/8387/6005>. Acesso em: 04 maio 2016.

BRASIL. Constituição da República dos Estados Unidos do Brasil. Rio de Janeiro: Diário Oficial da União, 1934. Disponível em: < http://www.planalto.gov.br/ccivil_03/Constituicao/Constituicao34.htm>. Acesso em: 07 jul. 2016.

BRASIL. Constituição da República Federativa do Brasil de 1988. Brasília: Senado Federal, 1988. Disponível em: < http://www.planalto.gov.br/ccivil_03/constituicao/constituicaocompilado.htm>. Acesso em: 07 jul. 2016.

BRASIL. Supremo Tribunal Federal. Ação Direta de Inconstitucionalidade $n^{\circ} 1856$. Requerente: Procurador-Geral da República. Relator: Ministro Celso de Mello. Brasília, DF, 26 de maio de 2011. Diário da Justiça Eletrônica. Brasília, 14 out. 2011. p. 275-340. Disponível em: 
<http://redir.stf.jus.br/paginadorpub/paginador.jsp?docTP=AC\&docID=628634>. Acesso em: 23 out. 2016.

BRASIL. Supremo Tribunal Federal. Ação Direta de Inconstitucionalidade no 4.983. Requerente: Procurador-Geral da República. Intimado: Governador do Estado do Ceará. Relator: Ministro Marco Aurélio. Brasília, DF, 12 de agosto de 2016. Diário da Justiça. Brasília, 12 ago. 2016. Disponível em: <http://www.stf.jus.br/arquivo/cms/noticiaNoticiaStf/anexo/ADI_4983.pdf>. Acesso em: 25 out. 2016.

BRASIL. Supremo Tribunal Federal. Recurso Extraordinário nº 153.531-8. Recorrente: Apande. Recorrido: Estado de Santa Catarina. Relator: Franscisco Rezek. Brasília, DF, 04 de fevereiro de 1997. Diário da Justiça. Brasília, 13 mar. 1998. p. 388-420. Disponível em:

$<$ http://redir.stf.jus.br/paginadorpub/paginador.jsp?docTP=AC\&docID=211500>. Acesso em: 23 out. 2016.

CADAVEZ, Lília Maria Vidal de Abreu Pinheiro. Crueldade contra os animais: uma leitura transdisciplinar à luz do sistema jurídico brasileiro. Revista Direito \& Justiça, Porto Alegre, v. 34, n. 1, p.88-120, jan./jun. 2008.

CARDOSO, Waleska Mendes. A fundamentação dos direitos dos animais não-humanos segundo a teoria reganiana. 2013. 154 f. Dissertação (Mestrado) - Curso de Filosofia, Universidade Federal de Santa Maria, Santa Maria, 2013.

CARDOSO, Waleska Mendes; TRINDADE, Gabriel Garmendia de. Por que os animais não são efetivamente protegidos: estudos sobre o antropocentrismo vigente a partir de um julgado emblemático. Revista brasileira de direito animal, Salvador, v. 8, n. 13, p. 201-214, 2013. Disponível em: <https://portalseer.ufba.br/index.php/RBDA/article/view/8643/6181>. Acesso em: 31 out. 2016.

CASTRO, João Marcos Adede y. Direitos dos animais na legislação brasileira. Porto Alegre: Sergio Antonio Fabris, 2006.

DIAS, Edna Cardoso. A defesa dos animais e as conquistas legislativas do movimento de proteção animal no Brasil. Revista Brasileira de Direito Animal, Salvador, v.2, n.2, p. 149-168, 2014. Disponível em: < http://www.portalseer.ufba.br/index.php/RBDA/article/view/10297/7357>. Acesso em: 18 out. 2016.

DOMINGUES, José. As ordenações Afonsinas: três séculos de Direito Medieval (1211-1512). Lisboa: Zéfiro, 2008.

FELIPE, Sônia F. Valor inerente vulnerabilidade: critérios éticos não especistas na perspectiva de Tom Regan.Ethic@, Florianópolis, v. 5, n. 3, p. 125-146, jul. 2006. Disponível em: < https://periodicos.ufsc.br/index.php/ethic/article/view/24877/22014>. Acesso em: 06 out. 2016.

FENSTERSEIFER, Tiago. Direito fundamentais e proteção do ambiente: a dimensão ecológica da dignidade humana no marco jurídico-constitucional do Estado Socioambiental de Direito. Porto Alegre: Livraria do Advogado, 2008.

FRANCIONE, Gary. Introdução aos direitos dos animais. Campinas: Unicamp, 2013. 
GORDILHO, Heron José de Santana. Abolicionismo animal. Salvador: Evolução, 2008.

LEVAI, Laerte Fernando. A luta pelos direitos animais no Brasil: passos para o futuro. Revista Brasileira de direito animal, Salvador, v. 7, n. 10, jan./jun. 2012, p. 175-187. Disponível em: <http://www.portalseer.ufba.br/index.php/RBDA/article/view/8402/6020>. Acesso em: 15 ago. 2016.

LEVAI, Fernando Laerte. Crueldade consentida: crítica à razão antropocêntrica. Revista Brasileira de Direito Animal, Salvador, v. 1, n.1, p. 171-190, 2006. Disponível em: $<$ https://portalseer.ufba.br/index.php/RBDA/article/view/10246/7303>. Acesso em: 01 nov. 2016.

MARTINS, Natália Luiza Alves. A proteção jurídica dos animais no direito brasileiro: por uma nova percepção do antropocentrismo. 2012. 134 f. Dissertação (Mestrado) - Curso de Direito, Direito, Universidade de Fortaleza, Fortaleza, 2012.

MAXIMILIANO, Carlos. Hermenêutica e Aplicação do Direito. 19 ed. Rio de Janeiro: Forense, 2006.

MEDEIROS, Fernanda Luiza Fontoura de. Direito dos animais. Porto Alegre: Livraria do Advogado, 2013.

NACONECY, Carlos Michelon. Ética \& Animais: um guia de argumentação filosófica. Porto Alegre: EDIPUCRS, 2006.

PASSOS, Carolina Ferraz. O desafio da proteção jurídica dos animais contra práticas de crueldade: hermenêutica constitucional. Revista da procuradoria geral do Estado de São Paulo, São Paulo, n. 81, p. 109-144, jan./jun. 2015.

PRIMATT, Humphry. A dissertation on the duty of mercy and sin of cruelty to brute animals. Londres: T. Cadell, 1776. 353 p. Disponível em:

<https://archive.org/stream/adissertationon00primgoog\#page/n0/mode/2up>. Acesso em: 01 jun. 2016.

PORTUGAL. Ordenações Filipinas: Quinto Livro. Rio de Janeiro: Instituto Philomatico, 1870. Disponível em: <http://www2.senado.leg.br/bdsf/item/id/242733>. Acesso em: 07 jul. 2016.

QUEIROZ, Cristina. Direitos fundamentais sociais: questões interpretativas e limites de justiciabilidade. In: SILVA, Virgílio Afonso da (org.). Interpretação constitucional. São Paulo: Malheiros Editores, 2005. p. 165-216.

REGAN, Tom. Defending animal rights. Chicago: University of Illinois, 2001.

REGAN, Tom. Jaulas Vazias: encarando o desafio dos direitos animais. Porto Alegre: Lugano, 2006.

REGAN, Tom. The case for animal rights. Berkeley: University of Carlifornia Press, 2004. 
SANTANA, Luciano rocha. Por uma releitura ética da atuação do Ministério Público em prol dos animais: estudo de casos da Primeira Promotoria de Justiça do Meio Ambiente de Salvador (Bahia). In: MOLINARO, Carlos Alberto; MEDEIROS, Fernanda Luiza Fontoura de; SARLET, Ingo Wolfgang; FENSTERSEIFER, Tiago (Org.). A dignidade da vida e os direitos fundamentais para além dos humanos: uma discussão necessária. Belo Horizonte: Fórum, 2008. p. 361-392.

SARLET, Ingo Wolfgang. A eficácia dos direitos fundamentais. Porto Alegre: Livraria do Advogado, 2003.

SARLET, Ingo Wolfgang; FENSTERSEIFER, Tiago. Algumas notas sobre a dimensão ecológica da dignidade da pessoa humana e sobre a dignidade da vida em geral. In: MOLINARO, Carlos Alberto; MEDEIROS, Fernanda Luiza Fontoura de; SARLET, Ingo Wolfgang; FENSTERSEIFER, Tiago (Org.). A dignidade da vida e os direitos fundamentais para além dos humanos: uma discussão necessária. Belo Horizonte: Fórum, 2008. p. 175-205.

SILVA, José Afonso da. Curso de Direito Constitucional Positivo. São Paulo: Malheiros, 2005.

SILVA, Tagore Trajano de Almeida. Fundamentos do Direito Animal Constitucional. In: CONPEDI, 18., 2009, São Paulo. Anais do XVIII Congresso Nacional do CONPEDI. São Paulo: Aa, 2009. p. 11126 - 11161. Disponível em:

<http://www.abolicionismoanimal.org.br/artigos/Fundamentos.pdf>. Acesso em: 11 set. 2016.

SILVA, Tagore Trajano de Almeida. Princípios de proteção animal na Constituição de 1988. Revista de Direito Brasileira, Florianópolis, v. 11, ano 5, p. 62 - 105, 2015. Disponível em: < http://www.rdb.org.br/ojs/index.php/rdb/article/view/267/212>. Acesso em 18 out. 2016.

SILVEIRA, Patrícia Azeredo da. AniMENOS: a condição dos animais no Direito brasileiro. In: MOLINARO, Carlos Alberto; MEDEIROS, Fernanda Luiza Fontoura de; SARLET, Ingo Wolfgang; FENSTERSEIFER, Tiago (Org.). A dignidade da vida e os direitos fundamentais para além dos humanos: uma discussão necessária. Belo Horizonte: Fórum, 2008. p. 175-205.

SINGER, Peter. Libertação animal: o clássico definitivo sobre o movimento pelos direitos dos animais. São Paulo: Martins Fontes, 2013.

VELOSO, Zeno. Controle jurisdicional de constitucionalidade: atualizado conforme as Leis 9.868 de 10.11.1999 e 9.8882 e 03.12.1999. Belo Horizonte: Del Rey, 2003. 